\title{
The Role of MSCs in the Tumor Microenvironment and Tumor Progression
}

\author{
SUNG YONG AHN \\ Department of Anatomy, Yonsei University College of Medicine, Seoul, Republic of Korea
}

\begin{abstract}
Over the past few decades, longevity without disease has become an important topic worldwide. However, as life expectancy increases, the number of patients with cancer is also increasing. Tumor progression is related to interactions between tumor cells and mesenchymal stem cells (MSCs) in the tumor microenvironment. MSCs are multipotent stromal cells known to be present in a variety of locations in the body, including bones, cartilage, fat, muscles, and dental pulp. MSCs migrate toward inflamed areas during pathological immune responses. MSCs also migrate toward tumor stroma and participate in tumor progression. MSCs can contribute to tumor progression by interacting with tumor cells via paracrine signaling and differentiate into diverse cell types. This also enables MSCs to make direct contact with tumor cells in tumor stroma. Interactions between tumor cells and MSCs enhance tumorigenic and metastatic potential, in addition to stimulating epithelial to mesenchymal transition. Herein, we reviewed the research associated with the tumor-enhancing role of MSCs in tumor progression, from primary tumor growth to distant tumor metastasis.
\end{abstract}

Mesenchymal stem cells (MSCs) are multipotent stromal cells $(1,2)$ with self-renewal abilities and the capacity to differentiate into osteoblasts, chondrocytes, and adipocytes $(3,4)$. MSCs usually express the lineage-specific markers CD73, CD90, and CD105 (2). MSCs generate anti-apoptotic factors, angiogenic factors, and growth factors, in addition to having chemo-attractive abilities (5). MSCs also have anti-

This article is freely accessible online.

Correspondence to: Sung Yong Ahn, Ph.D., Department of Anatomy, Yonsei University College of Medicine, 50-1 Yonsei-Ro, Seodaemun-gu, Seoul 03722, Republic of Korea. Tel: +82 222281666, Fax: +82 23650700, e-mail: sungyong@yuhs.ac

Key Words: Mesenchymal stem cells, tumor progression, tumor microenvironment, review. inflammatory and immunomodulatory properties (6-8). Their immunomodulatory and immunosuppressive properties are a promising therapeutic tool for inhibiting inflammation and suppressing pathological immune responses (5). A variety of research has reported the effects of treatment for systemic sepsis using MSCs (Table I).

Over the past few years, clinical trials of MSC treatment have been conducted for various pathologies, such as sepsis $(8,9)$ and graft-versus-host disease (10), and diverse autoimmune diseases $(11,12)$, such as ulcerative colitis (1), rheumatoid arthritis (11), and acute respiratory distress syndrome (13). Several clinical trials have been conducted with MSC treatment for sepsis-related diseases (Table II).

Conversely, MSCs contribute to cancer progression and metastasis when used for cancer treatment (14-17). The tumor microenvironment comprises various cell types, including endothelial cells, cancer-associated fibroblasts (CAFs), neutrophils, macrophages, lymphocytes, cancer stem cells, pericytes, as well as MSCs. According to recent research, MSCs home to tumor sites and are implicated in tumor growth and progression (16-19). In addition, several studies have shown that MSCs can enhance the metastatic ability of tumor cells by strengthening tumor cell motility and invasiveness, as well as creating a metastatic niche at secondary tumor sites (16, 20-22). MSCs are recruited to injured, inflamed, and hypoxic tumor milieu (23). During tumorigenesis, a variety of growth factors, cytokines, and chemokines secreted by tumor cells recruit MSCs to surround the tumor, which is associated with enhancement of the neoplastic properties of tumor cells. Therefore, comprehensive knowledge of the interaction mechanisms between tumor cells and MSCs in the tumor microenvironment is required.

\section{The Role of MSCs at the Primary Tumor Site}

MSCs were shown to be involved in tumor growth and progression in a number of cancer types, such as of the prostate (17), colon (24), gastric (25), breast $(16,26)$, head and neck (15), and in glioma (27), and follicular lymphoma (14). Breast 
cancer cell motility, invasiveness, and metastasis were enhanced by chemokine (C-C motif) ligand 5 (CCL5 also called RANTES) secreted from MSCs (16). Similarly, when human bone marrow MSCs and breast cancer cells were injected together, tumor invasion and metastasis were induced (28). MSCs have been reported to promote gastric (29) and breast (26) cancer metastasis via stimulation of epithelial to mesenchymal transition (EMT). This research suggests that MSCs may induce tumor cell metastasis at the primary tumor site. MSCs reportedly are recruited to the tumor by soluble factors secreted by tumor cells during tumorigenesis (30). Several studies have shown that cancer cells secrete various growth factors, cytokines, and chemokines, such as transforming growth factor beta (TGF $\beta$ ) and stromal cellderived factor 1 alpha $(\operatorname{SDF} 1 \alpha)(31)$, as well as interleukin 1 beta (IL1 $\beta$ ) (32). Breast cancer cells also secrete a large quantity of IL6, which activates and attracts MSCs to tumor under hypoxic conditions (23). A study has shown that MSCs secrete IL8, which promotes gastric cancer progression (25). MSCs also promote tumor growth and metastasis by means of paracrine effects and direct contact associated with expression of $\beta$-catenin and matrix metalloproteinase 16 (MMP16) (29).

\section{MSC Differentiation}

When MSCs surround a tumor, they can differentiate into more mature mesenchymal cells such as endothelial cells (33, 34), macrophages (35), and cancer-associated fibroblasts (CAFs) (36). Following differentiation, MSCs show outstanding phenotype changes, such as morphological elongation, diminished adhesion, reduced cytoskeletal fibers, and increased migration (37). CAFs are fibroblast-like cells with tumor-promoting function. According to several studies, CAFs are derived from bone marrow MSCs and fibroblasts, and transdifferentiate from epithelial and endothelial cells (3840). TGF $\beta$ expression was shown to contribute to MSC differentiation into CAFs via increased expression of alpha smooth muscle actin ( $\alpha$ SMA) and reduced expression of gelsolin (41). When TGF $\beta$ expression is accelerated, MSCs exhibit modified gene-expression profiles toward myofibroblast proteins, such as $\alpha$ SMA, fibroblast surface protein, and tenascin-C, in addition to growth-stimulating factors such as CCL5 and SDF1 $(42,43)$. Further mechanisms of differentiation of MSCs into CAFs are not yet fully understood. Nevertheless, TGF $\beta$ expression has been reported to promote morphologic changes in MSCs, regardless of the origin of the cells $(40,44-46)$. Under tumorigenic conditions, MSCs can differentiate into platelet-derived growth factor receptor-positive CAFs (47) or hematopoietic cells. The latter is mainly caused by reduced influx of $\mathrm{Ca}^{2+}(35,47)$. Taken together, in tumor stroma, various tumor-promoting factors secreted by tumor cells induce both morphological and geneexpression changes in MSCs.
Table I. Preclinical studies of treatment for systemic sepsis using mesenchymal stem cells (MSCs).

\begin{tabular}{lccc}
\hline Study & Animal & Sepsis & Cell therapy \\
\hline Hu et al., 2016 (92) & Mouse & LPS & hAd-MSCs \\
Shin et al., 2013 (93) & Rat & LPS & hAd-MSCs \\
Nemeth et al., 2009 (94) & Mouse & CLP & BM-MSC \\
Mei et al., 2010 (95) & Mouse & CLP & mMSCs \\
Dos Santos et al., 2012 (96) & Mouse & CLP & mMSCs \\
Krasnodembskaya et al., 2012 (97) & Mouse & GNPS & hMSCs \\
Luo et al., 2014 (98) & Mouse & CLP & mMSCs \\
Chao et al., 2014 (99) & Rat & CLP & hUC-MSCs and \\
& & & hBM-MSCs \\
Wang et al., 2015 (100) & Mouse & CLP & mMSCs \\
Alcayaga-Miranda et al., 2015 (101) & Mouse & CLP & Men-MSCs \\
\hline
\end{tabular}

Ad: Adipose tissue; CLP: cecal ligation and puncture; GNPS: Gramnegative polymicrobial sepsis; $\mathrm{h}$ : human; $\mathrm{m}$ : murine; LPS: lipopolysaccharide; UCB: umbilical cord blood-derived; BM: bone marrow-derived; Men: menstrual-derived.

\section{MSCs and EMT}

In tumor stroma, MSCs can induce cancer cell EMT. Directly co-culturing human breast or gastric cancer cells with MSCs was shown to increase the level of EMT markers, such as Ncadherin, TWIST, SNAIL, and vimentin, in addition to reducing the level of E-cadherin $(26,29)$. Similarly, the level of TGF $\beta$ secreted by tumor necrosis factor alpha (TNF $\alpha)$ and interferon gamma (IFN $\gamma$ )-treated human MSCs increased. When hepatocellular carcinoma cells were cultured in conditioned medium from TNF $\alpha$ - and IFN $\gamma$-treated human MSCs, their expression of EMT markers, migration, and invasion significantly increased both in vitro and in vivo (48). MSCs promoted cancer cell metastasis to the bones and lungs via EMT triggered by MSCs (49). Similarly, TGF $\beta 1$ secreted by MSCs enhanced EMT in MCF7 breast cancer cells; MSCs accelerated breast cancer cell metastasis by promoting the EMT process (50). MSCs were also found to modulate EMT and tumor progression during pancreatic cancer cell tumorigenesis (51).

\section{MSCs and Metastasis}

MSCs are involved in various stages of tumor progression (Figure 1). At the primary tumor site, MSCs induce tumor cells to have invasive and metastatic capacity. It has also been reported that both human and mouse MSCs enhance breast cancer metastasis (52). In tumor stroma, MSCs were reported to migrate and differentiate into CAFs. MSCs then induced colon cancer growth and metastasis by strengthening angiogenesis, motility, and invasiveness, and by suppressing cancer cell apoptosis (53). CAFs were also found to migrate from the primary tumor site to the lung metastatic site in mice 
Table II. Clinical trials using mesenchymal stem cells (MSCs) for sepsis-related diseases.

\begin{tabular}{lccc}
\hline Indication & Phase & Cell therapy & Clinical trial number* \\
\hline Septic shock and severe neutropenia & I & MSC & NCT01849237 \\
Cellular immunotherapy for septic shock & I & BM-MSC & NCT02421484 \\
Organ failure during septic shock & II & MSC (undefined) & NCT02883803 \\
Acute respiratory distress syndrome & I & BM-MSC & NCT01775774 \\
Acute respiratory distress syndrome & II & BM-MSC & NCT02097641 \\
Acute severe respiratory failure & II & BM-MSC & NCT02112500 \\
\hline
\end{tabular}

BM: Bone marrow. Phase I: safety testing; and phase II: efficacy testing. *At ClinicalTrials.gov.

(21). Similarly, hypoxia-inducible factors (HIFs) were found to relay paracrine signals between breast cancer cells, and MSCs promoted breast cancer metastasis (54).

\section{The Role of MSCs in Enhancement of Distant Metastasis}

When human MSCs and breast cancer cells were injected into mice, lung metastasis of breast cancer cells was stimulated by the increased interactions between CCL5 from MSCs and chemokine (C-C motif) receptor 5 (CCR5) from breast cancer cells (16). According to further research, CCL5 secreted by human MSCs promoted lung metastasis of osteosarcoma (55) and breast cancer cells (56). Furthermore, human MSCs isolated from metastatic sites (the liver and lung) expressed various CAF markers, such as $\alpha \mathrm{SMA}$, SDF1 $\alpha$, and MMP2 and MMP9 (56). Consequently, tumor-derived osteopontin (OPN) enhanced tumor growth and progression via the transformation of MSCs to CAFs (56). In several studies, increased OPN expression was associated with prostate cancer progression, in addition to being a landmark of distant metastasis enhancement (57-60). Increased OPN expression in breast cancer cells was also associated with osteolysis and bone metastasis $(61,62)$.

\section{The Role of MSCs in the Tumor Microenvironment}

MSCs contribute to tumor cell growth and metastasis in the tumor microenvironment (Table III). MSCs are implicated in multiple phases of cancer pathogenesis. A large number of bone marrow-derived MSCs were recruited to the tumor stroma during tumor development (63).

Stemness. The multilineage potential of MSCs accelerates tumor development. For instance, MSCs modulated the selfrenewal ability of breast cancer stem cells via cytokine networks, including IL6 and chemokine (C-X-C motif) ligand7 (CXCL7) (64). Human ovarian carcinoma-associated MSCs stimulated tumorigenesis by altering bone morphogenetic protein production (65). In addition to bone morphogenetic protein signaling, a variety of signaling pathways involving TGF $\beta$, WNT (66) and IL6/Janus kinase 2 (JAK2)/signal transducer and activator of transcription 3 (STAT3) $(67,68)$ enhanced the stemness of tumor cells. MSCs stimulated by carcinoma cells can create a carcinoma stem-cell niche, inducing carcinogenesis via production of large amounts of prostaglandin $\mathrm{E}_{2}(69)$.

Migration. EMT is an essential process in cancer cell migration, and can also facilitate carcinogenesis (70). EMT promotes cancer cell migration by inducing cancer cells to detach from the primary tumor site, and stimulates the subsequent metastasis of cancer cells $(70,71)$. In the tumor microenvironment, MSCs reinforce the metastatic potential of tumor cells by inducing tumor cell EMT after being recruited to the tumor site. When MSCs and breast cancer cells were cultured together, SNAIL family members SNAIL (SNAI1) and SLUG (SNAI2) (72), and vimentin expression increased but the expression of E-cadherin decreased (73). MSCs may also affect cancer cells via diverse mechanisms such as the CXCL1/CXCL5-chemokine (C-X-C motif) receptor 2 (CXCR2) (74), CCL5 and IL6 (75), and estrogen receptor (ER) and CXCR4 pathways (76) in breast cancer. MSCs also expedite prostate cancer cell invasion and migration by enhancing MMP2 and MMP9 expression (77).

Angiogenesis. Vascular endothelial growth factor (VEGF) expression by MSCs was found to contribute to pancreatic cancer angiogenesis (78). MSCs expedite tumor development in vivo by strengthening the neovascularization surrounding tumors (18). MSCs activate angiogenesis by secreting several soluble factors, such as macrophage colony-stimulating factor, leukemia inhibitory factor, macrophage inflammatory protein 2, VEGF (18), TNF $\alpha$, and IFN $\gamma$ (79).

Immunomodulation. Recent research has demonstrated the effects of MSC-based immunotherapy in allogeneic cell and tissue transplantation (80-82). It has been reported that MSCs have immunosuppressive or immunomodulatory properties 

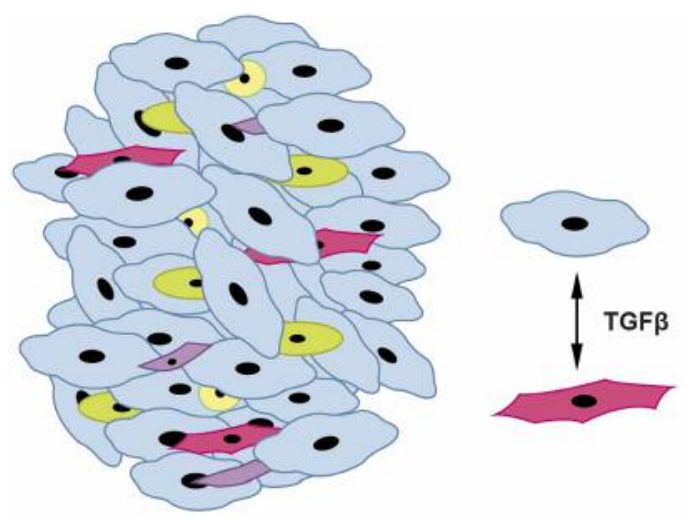

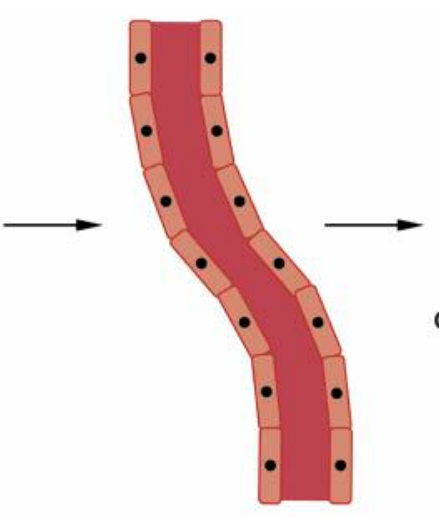

Blood vessel

Extravasation

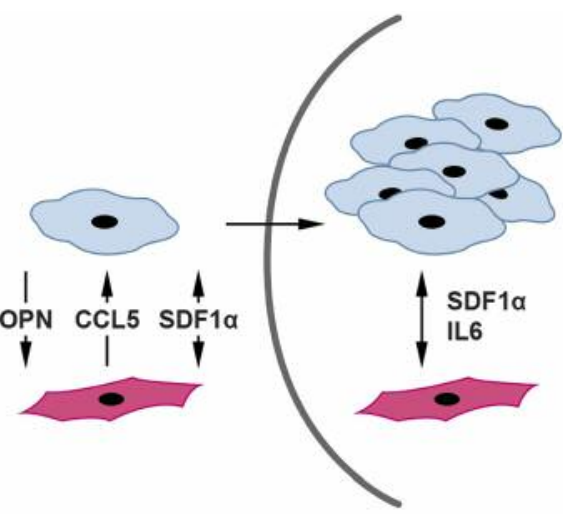

Metastatic site

Colonization

Proliferation

Migration

EMT

Invasion

Intravasation

\section{Tumor cell \\ Neutrophil}

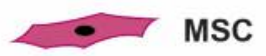

- Fibroblast

Endothelial cell

Figure 1. Interactions between mesenchymal stem cells (MSCs) and tumor cells during tumor progression. MSCs promote tumor progression from primary tumor sites to sites of metastasis by regulating various interactions between MSCs and tumor cells. MSCs have been shown to stimulate epithelial to mesenchymal transition (EMT) of tumor cells via direct cell to cell contact and transforming growth factor beta (TGF $\beta)$ secretion (48, 77). In addition, osteopontin (OPN) secreted by tumor cells induces chemokine (C-C motif) ligand 5 (CCL5) secretion of MSCs and promotes metastasis of breast cancer cells through interactions with chemokine (C-C motif) receptor 5 (CCR5) of breast cancer cells (56). Tumor cells secrete various growth factors, cytokines, and chemokines, such as stromal cell-derived factor 1 alpha (SDF1 $\alpha)(31)$ and interleukin 6 (IL6), which activates and attracts MSCs to the hypoxic tumor conditions (23). MSCs also affect tumor cells via SDF1a $(42,43)$ and IL6 secretion (64, 75).

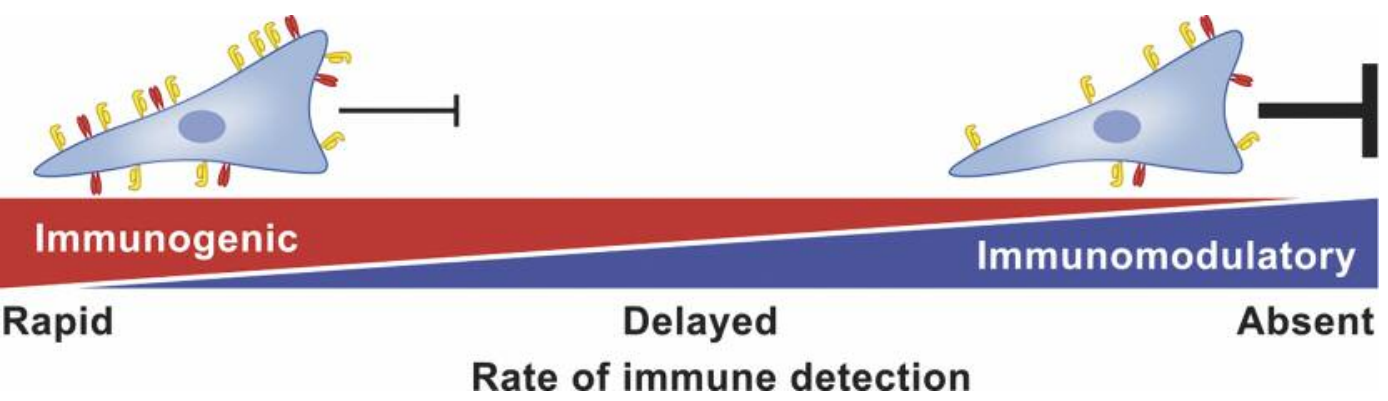

Figure 2. Immunomodulatory properties of mesenchymal stem cells (MSCs) enable immune evasion. Immunogenic MSCs express high levels of major histocompatibility complex (MHC) class I (in yellow) and II (in red) proteins, whereas immunomodulatory MSCs express low levels of MHC class I and II.

(5). Cytokines secreted by MSCs, such as TGF $\beta$ (83), IL10 (80), nitric oxide (84), prostaglandin E2 (10), and indoleamine 2,3-dioxygenase (85), are implicated in immunomodulation. According to previous research, the immunomodulatory properties of MSCs enable escape from host immune rejection $(86,87)$. The immunomodulatory properties of MSCs allow for the treatment of various inflammatory diseases (86). Furthermore, the sustainment of the effects of MSCs is related to the rate of their immune detection $(86,88)$. The rates of immune detection and removal of MSCs are determined by a balance between the relative expression of immunogenic and immunomodulatory 
Table III. Correlation between mesenchymal stem cells (MSCs) and tumor cells in the tumor microenvironment.

\begin{tabular}{lccc}
\hline Study & $\begin{array}{c}\text { Tumor } \\
\text { cell }\end{array}$ & $\begin{array}{c}\text { MSC } \\
\text { origin }\end{array}$ & $\begin{array}{c}\text { Tumor } \\
\text { function }\end{array}$ \\
\hline Prantl et al., 2010 (17) & Prostate & Ad & Promoting \\
Zhu et al., 2006 (24) & Colon & BM & Promoting \\
Li et al., 2015 (25) & Gastric & GC & Promoting \\
Martin et al., 2010 (26) & Breast & BM & Stimulating \\
Karnoub et al., 2007 (16) & Breast & BM & Promoting \\
Kansy et al., 2014 (15) & HN & HNSCC & Promoting \\
Hossain et al., 2015 (27) & Brain & GA & Increasing \\
Ame-Thomas et al., 2007 (14) & FL & BM & Supporting \\
Xue et al., 2015 (29) & Gastric & BM & Promoting \\
Shinagawa et al., 2010 (53) & Colon & IC & Enhancing \\
Xu et al., 2009 (55) & OS & BM & Promoting \\
Jing et al., 2012 (48) & HCC & BM & Accelerating \\
El-Haibi et al., 2012 (49) & Breast & BM & Promoting \\
Xu et al., 2012 (50) & Breast & Ad & Promoting \\
Kabashima-Niibe et al., 2013 (51) & Pancreas & BM & Promoting \\
Klopp et al., 2010 (73) & Breast & BM & Promoting \\
\hline
\end{tabular}

Ad: Adipose tissue; BM: bone marrow; FL: follicular lymphoma; GA glioma-associated; GC: gastric cancer; HCC: hepatocellular carcinoma; HN: head and neck; HNSCC: head and neck squamous cell carcinoma; IC: iliac crest; OS: osteosarcoma.

(immunosuppressive) factors of MSCs (Figure 2). Moreover, MSC-related immunomodulation has been diversely reported in tumor growth and progression. MSCs were shown to support breast cancer cells by enhancing regulatory $\mathrm{T}$-cell activity (89). In melanoma, the immunomodulatory function of MSCs was induced by TNF $\alpha$ and IFN $\gamma$. These cytokines promoted the expression of nitric oxide synthases by MSCs (90). The inflammatory cytokine IL1 $\alpha$ was found to induce the immunomodulatory properties of MSCs, enabling prostate cancer cells to avoid immunosurveillance (91).

\section{Conclusion}

MSCs are implicated in various stages of tumor progression. In summary, they are recruited to a tumor by soluble factors secreted by tumor cells during carcinogenesis. When MSCs surround the tumor, they can differentiate into more mature mesenchymal cells and promote tumor progression. In tumor stroma, MSCs stimulate EMT of cancer cells. Similarly, MSCs increase cancer cell motility and can induce metastatic colonization of cancer cells at distant metastatic sites. A variety of tumor-promoting factors secreted by tumor cells induce both phenotypic changes and modify the gene expression of MSCs. MSCs also promote tumor cell stemness, and angiogenesis, and can regulate immune responses through their immunosuppressive or immunomodulatory properties in the tumor microenvironment. Consequently, MSCs enhance tumor progression by regulating the tumor microenvironment. MSCs can therefore serve as an indicator of tumor progression. Several studies have shown that MSCs contribute to the growth and metastasis of tumor cells. MSCs are also involved in various stages of cancer pathogenesis. This suggests the potential of MSCs as a therapeutic target for the clinical treatment of patients with cancer.

\section{Conflicts of Interest}

The Author declares no conflicts of interest.

\section{Acknowledgements}

The Author expresses their thanks to Nari Jeon and Hee Chun Jeon for help with English proofreading and illustration, respectively.

\section{Funding}

This research was supported by the National Research Foundation of Korea (NRF) grant, funded by the Korean government (2017R1A6A3A11029376 to S.Y.A.).

\section{References}

1 Le Blanc K and Mougiakakos D: Multipotent mesenchymal stromal cells and the innate immune system. Nat Rev Immunol 12(5): 383-396, 2012. PMID: 22531326. DOI: 10.1038/nri3209

2 Dominici M, Le Blanc K, Mueller I, Slaper-Cortenbach I, Marini F, Krause D, Deans R, Keating A, Prockop D and Horwitz E: Minimal criteria for defining multipotent mesenchymal stromal cells. The International Society for Cellular Therapy position statement. Cytotherapy 8(4): 315-317, 2006. PMID: 16923606. DOI: $10.1080 / 14653240600855905$

3 Cardenas C, Kwon JY and Maeng YS: Human cord bloodderived CD133(+)/C-Kit(+)/Lin(-) cells have bipotential ability to differentiate into mesenchymal stem cells and outgrowth endothelial cells. Stem Cells Int 2016: 7162160, 2016. PMID: 28074098. DOI: $10.1155 / 2016 / 7162160$

4 Pittenger MF, Mackay AM, Beck SC, Jaiswal RK, Douglas R, Mosca JD, Moorman MA, Simonetti DW, Craig S and Marshak DR: Multilineage potential of adult human mesenchymal stem cells. Science 284(5411): 143-147, 1999. PMID: 10102814. DOI: $10.1126 /$ science. 284.5411 .143

5 Glenn JD and Whartenby KA: Mesenchymal stem cells: Emerging mechanisms of immunomodulation and therapy. World J Stem Cells 6(5): 526-539, 2014. PMID: 25426250. DOI: 10.4252/wjsc.v6.i5.526

6 Abumaree MH, Abomaray FM, Alshabibi MA, AlAskar AS and Kalionis B: Immunomodulatory properties of human placental mesenchymal stem/stromal cells. Placenta 59: 87-95, 2017. PMID: 28411943. DOI: 10.1016/j.placenta.2017.04.003

7 Zhang $\mathrm{H}$, Tao $\mathrm{Y}$, Liu $\mathrm{H}$, Ren $\mathrm{S}$, Zhang $\mathrm{B}$ and Chen $\mathrm{H}$ : Immunomodulatory function of whole human umbilical cord derived mesenchymal stem cells. Mol Immunol 87: 293-299, 2017. PMID: 28531813. DOI: 10.1016/j.molimm.2017.03.003

8 Ahn SY, Maeng YS, Kim YR, Choe YH, Hwang HS and Hyun $\mathrm{YM}$ : In vivo monitoring of dynamic interaction between neutrophil and human umbilical cord blood-derived mesenchymal 
stem cell in mouse liver during sepsis. Stem Cell Res Ther 11(1): 44, 2020. PMID: 32014040. DOI: 10.1186/s13287-020-1559-4

9 Keane C, Jerkic M and Laffey JG: Stem Cell-based Therapies for Sepsis. Anesthesiology 127(6): 1017-1034, 2017. PMID: 28872482. DOI: $10.1097 / A L N .0000000000001882$

10 Aggarwal S and Pittenger MF: Human mesenchymal stem cells modulate allogeneic immune cell responses. Blood 105(4): 18151822, 2005. PMID: 15494428. DOI: 10.1182/blood-2004-041559

11 Liu Y, Mu R, Wang S, Long L, Liu X, Li R, Sun J, Guo J, Zhang X, Guo J, Yu P, Li C, Liu X, Huang Z, Wang D, Li H, Gu Z, Liu $\mathrm{B}$ and $\mathrm{Li} \mathrm{Z}$ : Therapeutic potential of human umbilical cord mesenchymal stem cells in the treatment of rheumatoid arthritis. Arthritis Res Ther 12(6): R210, 2010. PMID: 21080925. DOI: $10.1186 /$ ar3187

$12 \mathrm{Xu} \mathrm{J}$ : Therapeutic applications of mesenchymal stem cells for systemic lupus erythematosus. Adv Exp Med Biol 1089: 73-85, 2018. PMID: 29767288. DOI: 10.1007/5584_2018_212

13 Wilson JG, Liu KD, Zhuo H, Caballero L, McMillan M, Fang X, Cosgrove K, Vojnik R, Calfee CS, Lee JW, Rogers AJ, Levitt J, Wiener-Kronish J, Bajwa EK, Leavitt A, McKenna D, Thompson BT and Matthay MA: Mesenchymal stem (stromal) cells for treatment of ARDS: A phase 1 clinical trial. Lancet Respir Med 3(1): 24-32, 2015. PMID: 25529339. DOI: 10.1016/S22132600(14)70291-7

14 Ame-Thomas P, Maby-El Hajjami H, Monvoisin C, Jean R, Monnier D, Caulet-Maugendre S, Guillaudeux T, Lamy T, Fest $\mathrm{T}$ and Tarte K: Human mesenchymal stem cells isolated from bone marrow and lymphoid organs support tumor B-cell growth: role of stromal cells in follicular lymphoma pathogenesis. Blood 109(2): 693-702, 2007. PMID: 16985173. DOI: 10.1182/blood2006-05-020800

15 Kansy BA, Dissmann PA, Hemeda H, Bruderek K, Westerkamp AM, Jagalski V, Schuler P, Kansy K, Lang S, Dumitru CA and Brandau S: The bidirectional tumor-mesenchymal stromal cell interaction promotes the progression of head and neck cancer. Stem Cell Res Ther 5(4): 95, 2014. PMID: 25115189. DOI: $10.1186 /$ scrt484

16 Karnoub AE, Dash AB, Vo AP, Sullivan A, Brooks MW, Bell GW, Richardson AL, Polyak K, Tubo R and Weinberg RA: Mesenchymal stem cells within tumour stroma promote breast cancer metastasis. Nature 449(7162): 557-563, 2007. PMID: 17914389. DOI: 10.1038 /nature06188

17 Prantl L, Muehlberg F, Navone NM, Song YH, Vykoukal J, Logothetis CJ and Alt EU: Adipose tissue-derived stem cells promote prostate tumor growth. Prostate 70(15): 1709-1715, 2010. PMID: 20564322. DOI: 10.1002/pros.21206

18 Suzuki K, Sun R, Origuchi M, Kanehira M, Takahata T, Itoh J, Umezawa A, Kijima H, Fukuda S and Saijo Y: Mesenchymal stromal cells promote tumor growth through the enhancement of neovascularization. Mol Med 17(7-8): 579-587, 2011. PMID: 21424106. DOI: $10.2119 /$ molmed 2010.00157

19 Kucerova L, Matuskova M, Hlubinova K, Altanerova V and Altaner C: Tumor cell behaviour modulation by mesenchymal stromal cells. Mol Cancer 9: 129, 2010. PMID: 20509882. DOI: 10.1186/1476-4598-9-129

20 Nabha SM, dos Santos EB, Yamamoto HA, Belizi A, Dong Z, Meng H, Saliganan A, Sabbota A, Bonfil RD and Cher ML: Bone marrow stromal cells enhance prostate cancer cell invasion through type I collagen in an MMP-12 dependent manner. Int J
Cancer 122(11): 2482-2490, 2008. PMID: 18324629. DOI: $10.1002 / \mathrm{ijc} .23431$

21 Duda DG, Duyverman AM, Kohno M, Snuderl M, Steller EJ, Fukumura D and Jain RK: Malignant cells facilitate lung metastasis by bringing their own soil. Proc Natl Acad Sci USA 107(50): 21677-21682, 2010. PMID: 21098274. DOI: 10.1073/pnas.1016234107

22 Corcoran KE, Trzaska KA, Fernandes H, Bryan M, Taborga M, Srinivas V, Packman K, Patel PS and Rameshwar P: Mesenchymal stem cells in early entry of breast cancer into bone marrow. PLoS One 3(6): e2563, 2008. PMID: 18575622. DOI: 10.1371/journal.pone.0002563

23 Rattigan Y, Hsu JM, Mishra PJ, Glod J and Banerjee D: Interleukin 6 mediated recruitment of mesenchymal stem cells to the hypoxic tumor milieu. Exp Cell Res 316(20): 3417-3424, 2010. PMID: 20633553. DOI: 10.1016/j.yexcr.2010.07.002

24 Zhu W, Xu W, Jiang R, Qian H, Chen M, Hu J, Cao W, Han $\mathrm{C}$ and Chen Y: Mesenchymal stem cells derived from bone marrow favor tumor cell growth in vivo. Exp Mol Pathol 80(3): 267-274, 2006. PMID: 16214129. DOI: 10.1016/j.yexmp.2005.07.004

25 Li W, Zhou Y, Yang J, Zhang X, Zhang H, Zhang T, Zhao S, Zheng P, Huo J and Wu H: Gastric cancer-derived mesenchymal stem cells prompt gastric cancer progression through secretion of interleukin-8. J Exp Clin Cancer Res 34: 52, 2015. PMID: 25986392. DOI: 10.1186/s13046-015-0172-3

26 Martin FT, Dwyer RM, Kelly J, Khan S, Murphy JM, Curran C, Miller N, Hennessy E, Dockery P, Barry FP, O’Brien T and Kerin MJ: Potential role of mesenchymal stem cells (MSCs) in the breast tumour microenvironment: stimulation of epithelial to mesenchymal transition (EMT). Breast Cancer Res Treat 124(2): 317-326, 2010. PMID: 20087650. DOI: 10.1007/s10549-0100734-1

27 Hossain A, Gumin J, Gao F, Figueroa J, Shinojima N, Takezaki T, Priebe W, Villarreal D, Kang SG, Joyce C, Sulman E, Wang Q, Marini FC, Andreeff M, Colman $H$ and Lang FF: Mesenchymal stem cells isolated from human gliomas increase proliferation and maintain stemness of glioma stem cells through the IL-6/GP130/STAT3 Pathway. Stem Cells 33(8): 2400-2415, 2015. PMID: 25966666. DOI: 10.1002/stem.2053

28 Lacerda L, Debeb BG, Smith D, Larson R, Solley T, Xu W, Krishnamurthy S, Gong Y, Levy LB, Buchholz T, Ueno NT, Klopp A and Woodward WA: Mesenchymal stem cells mediate the clinical phenotype of inflammatory breast cancer in a preclinical model. Breast Cancer Res 17: 42, 2015. PMID: 25887413. DOI: 10.1186/s13058-015-0549-4

29 Xue Z, Wu X, Chen X, Liu Y, Wang X, Wu K, Nie Y and Fan D: Mesenchymal stem cells promote epithelial to mesenchymal transition and metastasis in gastric cancer though paracrine cues and close physical contact. J Cell Biochem 116(4): 618-627, 2015. PMID: 25399738. DOI: 10.1002/jcb.25013

30 Ridge SM, Sullivan FJ and Glynn SA: Mesenchymal stem cells: Key players in cancer progression. Mol Cancer 16(1): 31, 2017. PMID: 28148268. DOI: 10.1186/s12943-017-0597-8

31 Gao H, Priebe W, Glod J and Banerjee D: Activation of signal transducers and activators of transcription 3 and focal adhesion kinase by stromal cell-derived factor 1 is required for migration of human mesenchymal stem cells in response to tumor cellconditioned medium. Stem Cells 27(4): 857-865, 2009. PMID: 19350687. DOI: $10.1002 /$ stem.23 
32 Tu S, Bhagat G, Cui G, Takaishi S, Kurt-Jones EA, Rickman B, Betz KS, Penz-Oesterreicher M, Bjorkdahl O, Fox JG and Wang TC: Overexpression of interleukin-1beta induces gastric inflammation and cancer and mobilizes myeloid-derived suppressor cells in mice. Cancer Cell 14(5): 408-419, 2008. PMID: 18977329. DOI: 10.1016/j.ccr.2008.10.011

33 Zhou Y, Guan X, Wang H, Zhu Z, Li C, WUSAnd Yu H: Hypoxia induces osteogenic/angiogenic responses of bone marrow-derived mesenchymal stromal cells seeded on bonederived scaffolds via ERK1/2 and p38 pathways. Biotechnol Bioeng 110(6): 1794-1804, 2013. PMID: 23296944. DOI: 10.1002/bit.24827

34 Janeczek Portalska K, Leferink A, Groen N, Fernandes H, Moroni L, van Blitterswijk C and de Boer J: Endothelial differentiation of mesenchymal stromal cells. PLoS One 7(10): e46842, 2012. PMID: 23056481. DOI: 10.1371 /journal.pone.0046842

35 Zhang L, Tang A, Zhou Y, Tang J, Luo Z, Jiang C, Li X, Xiang J and Li G: Tumor-conditioned mesenchymal stem cells display hematopoietic differentiation and diminished influx of $\mathrm{Ca} 2+$. Stem Cells Dev 21(9): 1418-1428, 2012. PMID: 21905919. DOI: $10.1089 / \mathrm{scd} .2011 .0319$

36 Direkze NC, Hodivala-Dilke K, Jeffery R, Hunt T, Poulsom R, Oukrif D, Alison MR and Wright NA: Bone marrow contribution to tumor-associated myofibroblasts and fibroblasts. Cancer Res 64(23): 8492-8495, 2004. PMID: 15574751. DOI: 10.1158/00085472.CAN-04-1708

37 McGrail DJ, Ghosh D, Quach ND and Dawson MR: Differential mechanical response of mesenchymal stem cells and fibroblasts to tumor-secreted soluble factors. PLoS One 7(3): e33248, 2012. PMID: 22438903. DOI: 10.1371/journal.pone.0033248

38 Spaeth EL, Dembinski JL, Sasser AK, Watson K, Klopp A, Hall B, Andreeff $\mathrm{M}$ and Marini F: Mesenchymal stem cell transition to tumor-associated fibroblasts contributes to fibrovascular network expansion and tumor progression. PLoS One 4(4): e4992, 2009 PMID: 19352430. DOI: 10.1371/journal.pone.0004992

39 Evans RA, Tian YC, Steadman R and Phillips AO: TGF-beta1mediated fibroblast-myofibroblast terminal differentiation-the role of SMAD proteins. Exp Cell Res 282(2): 90-100, 2003. PMID: 12531695. DOI: 10.1016/s0014-4827(02)00015-0

40 Zeisberg EM, Potenta S, Xie L, Zeisberg M and Kalluri R: Discovery of endothelial to mesenchymal transition as a source for carcinoma-associated fibroblasts. Cancer Res 67(21): 1012310128, 2007. PMID: 17974953. DOI: 10.1158/0008-5472.CAN07-3127

41 Wang D, Park JS, Chu JS, Krakowski A, Luo K, Chen DJ and Li $\mathrm{S}$ : Proteomic profiling of bone marrow mesenchymal stem cells upon transforming growth factor beta1 stimulation. J Biol Chem 279(42): 43725-43734, 2004. PMID: 15302865. DOI: 10.1074/jbc.M407368200

42 Quante M, Tu SP, Tomita H, Gonda T, Wang SS, Takashi S, Baik GH, Shibata W, Diprete B, Betz KS, Friedman R, Varro A, Tycko $\mathrm{B}$ and Wang TC: Bone marrow-derived myofibroblasts contribute to the mesenchymal stem cell niche and promote tumor growth. Cancer Cell 19(2): 257-272, 2011. PMID: 21316604. DOI: 10.1016/j.ccr.2011.01.020

43 Mishra PJ, Mishra PJ, Humeniuk R, Medina DJ, Alexe G, Mesirov JP, Ganesan S, Glod JW and Banerjee D: Carcinomaassociated fibroblast-like differentiation of human mesenchymal stem cells. Cancer Res 68(11): 4331-4339, 2008. PMID: 18519693. DOI: 10.1158/0008-5472.CAN-08-0943
44 Kojima Y, Acar A, Eaton EN, Mellody KT, Scheel C, Ben-Porath I, Onder TT, Wang ZC, Richardson AL, Weinberg RA and Orimo A: Autocrine TGF-beta and stromal cell-derived factor-1 (SDF1) signaling drives the evolution of tumor-promoting mammary stromal myofibroblasts. Proc Natl Acad Sci USA 107(46): 2000920014, 2010. PMID: 21041659. DOI: 10.1073/pnas.1013805107

45 Shangguan L, Ti X, Krause U, Hai B, Zhao Y, Yang Z and Liu F: Inhibition of TGF-beta/Smad signaling by BAMBI blocks differentiation of human mesenchymal stem cells to carcinomaassociated fibroblasts and abolishes their protumor effects. Stem Cells 30(12): 2810-2819, 2012. PMID: 23034983. DOI: 10.1002/stem.1251

46 Calon A, Tauriello DV and Batlle E: TGF-beta in CAF-mediated tumor growth and metastasis. Semin Cancer Biol 25: 15-22, 2014. PMID: 24412104. DOI: 10.1016/j.semcancer.2013.12.008

47 Shinagawa K, Kitadai Y, Tanaka M, Sumida T, Onoyama M, Ohnishi M, Ohara E, Higashi Y, Tanaka S, Yasui W and Chayama $\mathrm{K}$ : Stroma-directed imatinib therapy impairs the tumor-promoting effect of bone marrow-derived mesenchymal stem cells in an orthotopic transplantation model of colon cancer. Int J Cancer 132(4): 813-823, 2013. PMID: 22821812. DOI: 10.1002/ijc. 27735

48 Jing Y, Han Z, Liu Y, Sun K, Zhang S, Jiang G, Li R, Gao L, Zhao X, Wu D, Cai X, Wu M and Wei L: Mesenchymal stem cells in inflammation microenvironment accelerates hepatocellular carcinoma metastasis by inducing epithelialmesenchymal transition. PLoS One 7(8): e43272, 2012. PMID: 22952657. DOI: 10.1371/journal.pone.0043272

49 El-Haibi CP, Bell GW, Zhang J, Collmann AY, Wood D, Scherber CM, Csizmadia E, Mariani O, Zhu C, Campagne A, Toner M, Bhatia SN, Irimia D, Vincent-Salomon A and Karnoub AE: Critical role for lysyl oxidase in mesenchymal stem cell-driven breast cancer malignancy. Proc Natl Acad Sci USA 109(43): 1746017465, 2012. PMID: 23033492. DOI: 10.1073/pnas.1206653109

$50 \mathrm{Xu}$ Q, Wang L, Li H, Han Q, Li J, Qu X, Huang S and Zhao RC: Mesenchymal stem cells play a potential role in regulating the establishment and maintenance of epithelial-mesenchymal transition in MCF7 human breast cancer cells by paracrine and induced autocrine TGF-beta. Int J Oncol 41(3): 959-968, 2012. PMID: 22766682. DOI: 10.3892/ijo.2012.1541

51 Kabashima-Niibe A, Higuchi H, Takaishi H, Masugi Y, Matsuzaki Y, Mabuchi Y, Funakoshi S, Adachi M, Hamamoto Y, Kawachi S, Aiura K, Kitagawa Y, Sakamoto M and Hibi T: Mesenchymal stem cells regulate epithelial-mesenchymal transition and tumor progression of pancreatic cancer cells. Cancer Sci 104(2): 157164, 2013. PMID: 23121112. DOI: 10.1111/cas.12059

52 Albarenque SM, Zwacka RM and Mohr A: Both human and mouse mesenchymal stem cells promote breast cancer metastasis. Stem Cell Res 7(2): 163-171, 2011. PMID: 21763624. DOI: 10.1016/j.scr.2011.05.002

53 Shinagawa K, Kitadai Y, Tanaka M, Sumida T, Kodama M, Higashi Y, Tanaka S, Yasui W and Chayama K: Mesenchymal stem cells enhance growth and metastasis of colon cancer. Int $\mathbf{J}$ Cancer 127(10): 2323-2333, 2010. PMID: 20473928. DOI: $10.1002 /$ ijc. 25440

54 Chaturvedi P, Gilkes DM, Wong CC, Kshitiz, Luo W, Zhang H, Wei H, Takano N, Schito L, Levchenko A and Semenza GL: Hypoxia-inducible factor-dependent breast cancer-mesenchymal stem cell bidirectional signaling promotes metastasis. J Clin Invest 123(1): 189-205, 2013. PMID: 23318994. DOI: 10.1172/JCI64993 
$55 \mathrm{Xu}$ WT, Bian ZY, Fan QM, Li G and Tang TT: Human mesenchymal stem cells (hMSCs) target osteosarcoma and promote its growth and pulmonary metastasis. Cancer Lett 281(1): 32-41, 2009. PMID: 19342158. DOI: 10.1016/j.canlet.2009.02.022

56 Mi Z, Bhattacharya SD, Kim VM, Guo H, Talbot LJ and Kuo PC: Osteopontin promotes CCL5-mesenchymal stromal cellmediated breast cancer metastasis. Carcinogenesis 32(4): $477-$ 487, 2011. PMID: 21252118. DOI: 10.1093/carcin/bgr009

57 Khodavirdi AC, Song Z, Yang S, Zhong C, Wang S, Wu H, Pritchard C, Nelson PS and Roy-Burman P: Increased expression of osteopontin contributes to the progression of prostate cancer. Cancer Res 66(2): 883-888, 2006. PMID: 16424021. DOI: 10.1158/0008-5472.CAN-05-2816

58 Castellano G, Malaponte G, Mazzarino MC, Figini M, Marchese F, Gangemi P, Travali S, Stivala F, Canevari S and Libra M: Activation of the osteopontin/matrix metalloproteinase-9 pathway correlates with prostate cancer progression. Clin Cancer Res 14(22): 7470-7480, 2008. PMID: 19010864. DOI: 10.1158/10780432.CCR-08-0870

59 Forootan SS, Foster CS, Aachi VR, Adamson J, Smith PH, Lin $\mathrm{K}$ and $\mathrm{Ke} \mathrm{Y}$ : Prognostic significance of osteopontin expression in human prostate cancer. Int J Cancer 118(9): 2255-2261, 2006. PMID: 16331611. DOI: 10.1002/ijc.21619

60 Ramankulov A, Lein M, Kristiansen G, Loening SA and Jung K: Plasma osteopontin in comparison with bone markers as indicator of bone metastasis and survival outcome in patients with prostate cancer. Prostate 67(3): 330-340, 2007. PMID: 17192877. DOI: $10.1002 /$ pros. 20540

61 Ibrahim T, Leong I, Sanchez-Sweatman O, Khokha R, Sodek J, Tenenbaum HC, Ganss B and Cheifetz S: Expression of bone sialoprotein and osteopontin in breast cancer bone metastases. Clin Exp Metastasis 18(3): 253-260, 2000. PMID: 11315099. DOI: $10.1023 / \mathrm{a}: 1006754605901$

62 Adwan H, Bauerle TJ and Berger MR: Downregulation of osteopontin and bone sialoprotein II is related to reduced colony formation and metastasis formation of MDA-MB-231 human breast cancer cells. Cancer Gene Ther 11(2): 109-120, 2004. PMID: 14647232. DOI: 10.1038/sj.cgt.7700659

63 Hall B, Andreeff $M$ and Marini F: The participation of mesenchymal stem cells in tumor stroma formation and their application as targeted-gene delivery vehicles. Handb Exp Pharmacol 180: 263-283, 2007. PMID: 17554513. DOI: 10.1007/978-3-540-68976-8_12

64 Liu S, Ginestier C, Ou SJ, Clouthier SG, Patel SH, Monville F, Korkaya H, Heath A, Dutcher J, Kleer CG, Jung Y, Dontu G, Taichman $\mathrm{R}$ and Wicha MS: Breast cancer stem cells are regulated by mesenchymal stem cells through cytokine networks. Cancer Res 71(2): 614-624, 2011. PMID: 21224357. DOI: 10.1158/0008-5472.CAN-10-0538

65 McLean K, Gong Y, Choi Y, Deng N, Yang K, Bai S, Cabrera L, Keller E, McCauley L, Cho KR and Buckanovich RJ: Human ovarian carcinoma-associated mesenchymal stem cells regulate cancer stem cells and tumorigenesis via altered BMP production. J Clin Invest 121(8): 3206-3219, 2011. PMID: 21737876. DOI: $10.1172 / \mathrm{JCI} 45273$

66 Nishimura K, Semba S, Aoyagi K, Sasaki H and Yokozaki H: Mesenchymal stem cells provide an advantageous tumor microenvironment for the restoration of cancer stem cells. Pathobiology 79(6): 290-306, 2012. PMID: 22688186. DOI: $10.1159 / 000337296$
67 Hsu HS, Lin JH, Hsu TW, Su K, Wang CW, Yang KY, Chiou SH and Hung SC: Mesenchymal stem cells enhance lung cancer initiation through activation of IL-6/JAK2/STAT3 pathway. Lung Cancer 75(2): 167-177, 2012. PMID: 21802163. DOI: 10.1016/j.lungcan.2011.07.001

68 Tsai KS, Yang SH, Lei YP, Tsai CC, Chen HW, Hsu CY, Chen LL, Wang HW, Miller SA, Chiou SH, Hung MC and Hung SC: Mesenchymal stem cells promote formation of colorectal tumors in mice. Gastroenterology 141(3): 1046-1056, 2011. PMID: 21699785. DOI: 10.1053 /j.gastro.2011.05.045

69 Li HJ, Reinhardt F, Herschman HR and Weinberg RA: Cancerstimulated mesenchymal stem cells create a carcinoma stem cell niche via prostaglandin E2 signaling. Cancer Discov 2(9): 840-855, 2012. PMID: 22763855. DOI: 10.1158/2159-8290.CD-12-0101

70 Thiery JP and Sleeman JP: Complex networks orchestrate epithelial-mesenchymal transitions. Nat Rev Mol Cell Biol 7(2): 131-142, 2006. PMID: 16493418. DOI: 10.1038/nrm1835

71 Brabletz T, Jung A, Spaderna S, Hlubek F and Kirchner T: Opinion: migrating cancer stem cells - an integrated concept of malignant tumour progression. Nat Rev Cancer 5(9): 744-749, 2005. PMID: 16148886 . DOI: $10.1038 /$ nrc1694

72 Cho ES, Kang HE, Kim NH and Yook JI: Therapeutic implications of cancer epithelial-mesenchymal transition (EMT). Arch Pharm Res 42(1): 14-24, 2019. PMID: 30649699. DOI: 10.1007/s12272-018-01108-7

73 Klopp AH, Lacerda L, Gupta A, Debeb BG, Solley T, Li L, Spaeth E, Xu W, Zhang X, Lewis MT, Reuben JM, Krishnamurthy S, Ferrari M, Gaspar R, Buchholz TA, Cristofanilli M, Marini F, Andreeff $\mathrm{M}$ and Woodward WA: Mesenchymal stem cells promote mammosphere formation and decrease E-cadherin in normal and malignant breast cells. PLoS One 5(8): e12180, 2010. PMID: 20808935. DOI: 10.1371/journal.pone.0012180

74 Halpern JL, Kilbarger A and Lynch CC: Mesenchymal stem cells promote mammary cancer cell migration in vitro via the CXCR2 receptor. Cancer Lett 308(1): 91-99, 2011. PMID: 21601983. DOI: $10.1016 /$ j.canlet.2011.04.018

75 Gallo M, De Luca A, Lamura L and Normanno N: Zoledronic acid blocks the interaction between mesenchymal stem cells and breast cancer cells: implications for adjuvant therapy of breast cancer. Ann Oncol 23(3): 597-604, 2012. PMID: 21551002. DOI: 10.1093/annonc/mdr159

76 Rhodes LV, Antoon JW, Muir SE, Elliott S, Beckman BS and Burow ME: Effects of human mesenchymal stem cells on ERpositive human breast carcinoma cells mediated through ERSDF-1/CXCR4 crosstalk. Mol Cancer 9: 295, 2010. PMID: 21087507. DOI: 10.1186/1476-4598-9-295

77 Ye H, Cheng J, Tang Y, Liu Z, Xu C, Liu Y and Sun Y: Human bone marrow-derived mesenchymal stem cells produced TGFbeta contributes to progression and metastasis of prostate cancer. Cancer Invest 30(7): 513-518, 2012. PMID: 22646310. DOI: 10.3109/07357907.2012.692171

78 Beckermann BM, Kallifatidis G, Groth A, Frommhold D, Apel A, Mattern J, Salnikov AV, Moldenhauer G, Wagner W, Diehlmann A, Saffrich R, Schubert M, Ho AD, Giese N, Buchler MW, Friess H, Buchler P and Herr I: VEGF expression by mesenchymal stem cells contributes to angiogenesis in pancreatic carcinoma. Br J Cancer 99(4): 622-631, 2008. PMID: 18665180. DOI: $10.1038 /$ sj.bjc. 6604508

79 Liu Y, Han ZP, Zhang SS, Jing YY, Bu XX, Wang CY, Sun K, Jiang GC, Zhao X, Li R, Gao L, Zhao QD, Wu MC and Wei LX: 
Effects of inflammatory factors on mesenchymal stem cells and their role in the promotion of tumor angiogenesis in colon cancer. J Biol Chem 286(28): 25007-25015, 2011. PMID: 21592963. DOI: $10.1074 / \mathrm{jbc} . M 110.213108$

80 Batten P, Sarathchandra P, Antoniw JW, Tay SS, Lowdell MW, Taylor PM and Yacoub MH: Human mesenchymal stem cells induce T-cell anergy and downregulate T-cell allo-responses via the TH2 pathway: Relevance to tissue engineering human heart valves. Tissue Eng 12(8): 2263-2273, 2006. PMID: 16968166. DOI: $10.1089 /$ ten.2006.12.2263

81 Casiraghi F, Perico N and Remuzzi G: Mesenchymal stromal cells to promote solid organ transplantation tolerance. Curr Opin Organ Transplant 18(1): 51-58, 2013. PMID: 23254705. DOI: 10.1097/MOT.0b013e32835c5016

82 Reinders ME, de Fijter JW, Roelofs H, Bajema IM, de Vries DK, Schaapherder AF, Claas FH, van Miert PP, Roelen DL, van Kooten C, Fibbe WE and Rabelink TJ: Autologous bone marrowderived mesenchymal stromal cells for the treatment of allograft rejection after renal transplantation: Results of a phase I study. Stem Cells Transl Med 2(2): 107-111, 2013. PMID: 23349326. DOI: $10.5966 /$ sctm.2012-0114

83 Groh ME, Maitra B, Szekely E and Koc ON: Human mesenchymal stem cells require monocyte-mediated activation to suppress alloreactive T-cells. Exp Hematol 33(8): 928-934, 2005. PMID: 16038786. DOI: 10.1016/j.exphem.2005.05.002

84 Sato K, Ozaki K, Oh I, Meguro A, Hatanaka K, Nagai T, Muroi K and Ozawa K: Nitric oxide plays a critical role in suppression of Tcell proliferation by mesenchymal stem cells. Blood 109(1): 228234, 2007. PMID: 16985180. DOI: 10.1182/blood-2006-02-002246

85 Meisel R, Zibert A, Laryea M, Gobel U, Daubener W and Dilloo D: Human bone marrow stromal cells inhibit allogeneic T-cell responses by indoleamine 2,3-dioxygenase-mediated tryptophan degradation. Blood 103(12): 4619-4621, 2004. PMID: 15001472. DOI: 10.1182/blood-2003-11-3909

86 Ankrum JA, Ong JF and Karp JM: Mesenchymal stem cells: Immune evasive, not immune privileged. Nat Biotechnol 32(3): 252-260, 2014. PMID: 24561556. DOI: 10.1038/nbt.2816

87 Owens SD, Kol A, Walker NJ and Borjesson DL: Allogeneic mesenchymal stem cell treatment induces specific alloantibodies in horses. Stem Cells Int 2016: 5830103, 2016. PMID: 27648075. DOI: $10.1155 / 2016 / 5830103$

88 Lee M, Jeong SY, Ha J, Kim M, Jin HJ, Kwon SJ, Chang JW, Choi SJ, Oh W, Yang YS, Kim JS and Jeon HB: Low immunogenicity of allogeneic human umbilical cord bloodderived mesenchymal stem cells in vitro and in vivo. Biochem Biophys Res Commun 446(4): 983-989, 2014. PMID: 24657442. DOI: $10.1016 /$ j.bbrc.2014.03.051

89 Patel SA, Meyer JR, Greco SJ, Corcoran KE, Bryan M and Rameshwar P: Mesenchymal stem cells protect breast cancer cells through regulatory $\mathrm{T}$ cells: role of mesenchymal stem cellderived TGF-beta. J Immunol 184(10): 5885-5894, 2010. PMID: 20382885. DOI: $10.4049 /$ jimmunol.0903143

90 Han Z, Tian Z, Lv G, Zhang L, Jiang G, Sun K, Wang C, Bu X, Li R, Shi Y, Wu M and Wei L: Immunosuppressive effect of bone marrow-derived mesenchymal stem cells in inflammatory microenvironment favours the growth of B16 melanoma cells. J Cell Mol Med 15(11): 2343-2352, 2011. PMID: 21091630. DOI: 10.1111/j.1582-4934.2010.01215.x

91 Cheng J, Li L, Liu Y, Wang Z, Zhu X and Bai X: Interleukin1alpha induces immunosuppression by mesenchymal stem cells promoting the growth of prostate cancer cells. Mol Med Rep 6(5): 955-960, 2012. PMID: 22895682. DOI: 10.3892/mmr.2012.1019

$92 \mathrm{Hu} \mathrm{Y,} \mathrm{Qin} \mathrm{C,} \mathrm{Zheng} \mathrm{G,} \mathrm{Lai} \mathrm{D,} \mathrm{Tao} \mathrm{H,} \mathrm{Zhang} \mathrm{Y,} \mathrm{Qiu} \mathrm{G,} \mathrm{Ge} \mathrm{M,}$ Huang L, Chen L, Cheng B, Shu Q and Xu J: Mesenchymal stem cell-educated macrophages ameliorate lps-induced systemic response. Mediators Inflamm 2016: 3735452, 2016. PMID: 27546994. DOI: $10.1155 / 2016 / 3735452$

93 Shin S, Kim Y, Jeong S, Hong S, Kim I, Lee W and Choi S: The therapeutic effect of human adult stem cells derived from adipose tissue in endotoxemic rat model. Int J Med Sci 10(1): 8-18, 2013. PMID: 23289000. DOI: 10.7150/ijms.5385

94 Nemeth K, Leelahavanichkul A, Yuen PS, Mayer B, Parmelee A, Doi K, Robey PG, Leelahavanichkul K, Koller BH, Brown JM, $\mathrm{Hu}$ X, Jelinek I, Star RA and Mezey E: Bone marrow stromal cells attenuate sepsis via prostaglandin E(2)-dependent reprogramming of host macrophages to increase their interleukin10 production. Nat Med 15(1): 42-49, 2009. PMID: 19098906. DOI: $10.1038 / \mathrm{nm} .1905$

95 Mei SH, Haitsma JJ, Dos Santos CC, Deng Y, Lai PF, Slutsky AS, Liles WC and Stewart DJ: Mesenchymal stem cells reduce inflammation while enhancing bacterial clearance and improving survival in sepsis. Am J Respir Crit Care Med 182(8): 1047-1057, 2010. PMID: 20558630. DOI: 10.1164/rccm.201001-0010OC

96 dos Santos CC, Murthy S, Hu P, Shan Y, Haitsma JJ, Mei SH, Stewart DJ and Liles WC: Network analysis of transcriptional responses induced by mesenchymal stem cell treatment of experimental sepsis. Am J Pathol 181(5): 1681-1692, 2012. PMID: 23083833. DOI: 10.1016/j.ajpath.2012.08.009

97 Krasnodembskaya A, Samarani G, Song Y, Zhuo H, Su X, Lee JW, Gupta N, Petrini M and Matthay MA: Human mesenchymal stem cells reduce mortality and bacteremia in gram-negative sepsis in mice in part by enhancing the phagocytic activity of blood monocytes. Am J Physiol Lung Cell Mol Physiol 302(10): L10031013, 2012. PMID: 22427530. DOI: 10.1152/ajplung.00180.2011

98 Luo CJ, Zhang FJ, Zhang L, Geng YQ, Li QG, Hong Q, Fu B, Zhu F, Cui SY, Feng Z, Sun XF and Chen XM: Mesenchymal stem cells ameliorate sepsis-associated acute kidney injury in mice. Shock 41(2): 123-129, 2014. PMID: 24169208. DOI: 10.1097/SHK.0000000000000080

99 Chao YH, Wu HP, Wu KH, Tsai YG, Peng CT, Lin KC, Chao WR, Lee $\mathrm{MS}$ and $\mathrm{Fu} \mathrm{YC}$ : An increase in $\mathrm{CD} 3{ }^{+} \mathrm{CD} 4{ }^{+} \mathrm{CD} 25^{+}$regulatory T-cells after administration of umbilical cord-derived mesenchymal stem cells during sepsis. PLoS One 9(10): e110338, 2014. PMID: 25337817. DOI: 10.1371 /journal.pone. 0110338

100 Wang X, Gu H, Qin D, Yang L, Huang W, Essandoh K, Wang Y, Caldwell CC, Peng T, Zingarelli B and Fan GC: Exosomal miR-223 contributes to mesenchymal stem cell-elicited cardioprotection in polymicrobial sepsis. Sci Rep 5: 13721, 2015. PMID: 26348153. DOI: 10.1038/srep13721

101 Alcayaga-Miranda F, Cuenca J, Martin A, Contreras L, Figueroa FE and Khoury M: Combination therapy of menstrual derived mesenchymal stem cells and antibiotics ameliorates survival in sepsis. Stem Cell Res Ther 6: 199, 2015. PMID: 26474552. DOI: $10.1186 / \mathrm{s} 13287-015-0192-0$

Received April 6, 2020

Revised April 20, 2020

Accepted April 21, 2020 